\section{Auscultation of the Heart and Phonocardiography}

By Aubrey Leatham. Pp. 151, illustrated. I.ondon: J. \& A. Churchill, 1970. $£ 7.00$.

Since his Goulstonian Lectures of 1958 we have awaited a definitive textbook by the author who is one of the leading contributors to modern phonocardiography. At long last this has appeared in a concise book of 150 pages. Such condensation has resulted in an extremely 'meaty' work with no superfluous verbiage. This concentration of factual material results in a readable reference book; best assimilated in repeated small doses.

As indicated by the title, it is no textbook of phonocardiography alone, but is equally intended for training the reader in the arts of auscultation. The basic principles of stethoscopy are reviewed, followed by chapters dealing with the normal cardiac cycle, heart sounds and their behaviour, normal and abnormal, extra sounds and murmurs, all considered clinically as well as by phonocardiography. To illustrate almost every point, phonocardiograms of first class quality are reproduced and these, together with the excellent diagrams, amply explain each point the author makes.

To the many who consider cardiologists' interpretation of sounds and murmurs to be largely imagination or 'oneupmanship', this work should provide the answer!

There has long been a need for such a book, notably amongst all those training in auscultation. This work admirably provides for this, and is most highly recommended. It should be found on the shelf of each MRCP candidate as well as with the works of reference in the library of established general physician and cardiologist alike. The undergraduate too will find it of value for reference, and it should certainly be available in all Medical School libraries.

\section{The Biology of Large RNA Viruses}

Edited by R. D. BARkY and B. W. MABY. Pp. 736, illus trated. London: Academic Press, 1970. £10.00.

The large RNA viruses include influenza, parainfluenza vesicular stomatitis, rabies, and the leukoviruses which produce leukaemia and sarcoma in fowls. These viruses arecharacterized by size; structural complexity; maturation of: the virus particle at the cell surface, involving conversion of the cell membrane into the virus envelope; the apparent existence within the virus particle of a fragmented RNF genome; and participation of DNA in the replication of viru RNA. The fact that some of these viruses induce transformation of the host cell, and the intimate association of theis replication with normal cell processes, emphasize the ingredients for a most appealing symposium on their biology? This was held in Cambridge in July 1969, and this large volume comprises the papers in the course of 5 days. All contributors were asked to include a review of relevant background information for the non-specialized reader, sô these transactions are of general biological interest to micro응 biologists, biochemists, molecular biologists, epidemiologist cancer workers, and clinicians particularly interested in in fectious disease.

The book is divided into eight sections devoted to structure and intracellular localization of the large RNA viruseser virus-cell interactions, virus-host interactions, properties an of replication of RNA, genetics, synthesis of protein and otheo structural components, and the functional modification in virus-infected cells.

The final product is a splendid tribute to the participaots editors, publisher, and generous financial backers of 而is. worthwhile symposium. 